\title{
THE THERMAL EFFECTS OF PULSED ULTRASOUND.
}

\author{
V. SANDLER, B.Sc. (Physiotherapy) Witwatersrand and P. FEINGOLD, B.Sc. (Physiotherapy) Witwatersrand
}

\section{SUMMARY}

Heat production by pulsed ultrasound was investigated. Four thermocouples were inserted into the thighs of each of six rabbits at specified depths. Temperature changes were recorded during insonation at different frequencies, intensities and duration of insonation. Significant thermal effects were recorded at both pulse ratios. These temperature increases were greater using a pulse ratio of $1: 1$ than a pulse ratio of $1: 4$, but less than those produced by a continuous beam.

\section{INTRODUCTION}

Pulsed ultrasound waves are short trains of rectangular waves propagated at regular intervals, resulting in a period of emission followed by a period of rest. The intensity of the ultrasound beam remains unchanged for each pulse when the continuous beam is modulated. The amplitude of the oscillations is therefore unaltered with pulsation and the same intensity is transferred to the tissues. Due to the fractionated time of application, the overall dose of ultrasound is correspondingly reduced.

The heating effects due to ultrasound are decreased by pulsing the beam. The intervals between pulses allow heat dissipation by convection via the blood stream. The mechanical and chemical effects of ultrasound take four times as long as the heating effects to decline. The interval between two consecutive pulses may be set to allow complete dissipation of heat before the next impulse, whereas the biological effects decline minimally during this period. The biological effects due to the following pulse are cumulative so that the token biological effect is increased. It has been noted (Summer and Patrick, 1964) that with a pulse of $2 \mathrm{msec}$. duration an interval of at least $8 \mathrm{msec}$. is required to e'iminate accumulation of heat. This means that a pulse ratio greater than $1: 4$ will produce heating of the tissues (Figure 1) (Bauer. I954: Faris. 1969; Miller and Weaver, 1954; Scott, 1975; Summer and Patrick, 1964). If a continuous beam of ultrasound is administered at $1 \mathrm{~W} / \mathrm{cm}^{2}$ ior 10 minutes the total energy output (or dosage) delivered to the patient will be $10 \mathrm{Wmin} / \mathrm{cm}^{2}$. If the beam is pulsed at a ratio of $1: 1$ for the same intensity and times, the ultrasound energy is delivered for only half the treatment time and the effective dose will therefore be halved, i.e. $5 \mathrm{Wmin} / \mathrm{cm}^{2}$ (Summer and Fatrick, 1964). Similarly with a pulse ratio of $1: 4$ for the same intensity and time, the total output will be only $2 \mathrm{Wmin} / \mathrm{cm}^{2}$. The dosage administered should be the minimum necessary to bring about the required effect. When treating a specific condition the intensity should NOT be altered when pulsing the beam as higher intensities may exacerbate the condition (Mitchell, 1980).

The mechanical effects of pulsed ultrasound are:

- Micro-massage and acoustic streaming.

- Cavitation.

- Acceleration and diffusion of particles.

- Vibration of cells and tissues.

* This paper is based on research done as a final year project at the University of the Witwatersrand (1980). Received 22 December 1980.

\section{OPSOMMING}

Die hitte geproduseer deur gepulseerde ultraklank is ondersoek. Vier termokoppels is in die dy van elk van ses hase op spesifieke dieptes geplaas. Temperatuurverskille gedurende insonasie by verskillende frekwen. sies, intensiteite en duurtes van insonasie is aangeteken. Betekenisvolle termiese effekte is by beide pulsverhoudings aangeteken. Hierdie temperatuurverhogings was groler wanneer ' $n$ pulsverhouding van $1: 1$ gebruik is in vergelyking met 'n pulsverhouding van $1: 4$, maar minder as diê wat deur' $n$ onafgebroke straal geproduseer is.

The biochemical effects include:

- Alteration of tissue respiration and $\mathrm{pH}$.

- Mixing of cell plasma.

- Formation and/or breakdown of molecules (Summer and Patrick, 1964).

Thermal and micro-massage effects together cause the release of a histamine-like substance resulting in spasmolysis and capillary hyperaemia (Summer and Patrick, 1964).

The mechanical and biochemical effects result in the following physiological effects:

- Acceleration of local blood flow as a result of mechanical vibration and neural effects.

- Interference with transmission of pain impulses to receptor centres in the brain, resulting in pain relief. The nerve fibres involved in vascular responses are particularly sensitive to ultrasound energy (Griffin, 1966; Licht, 1958).

- Increased membrane permeability.

- Greater efficiency of muscle action (Griffin et al., 1970).

- Facilitation of synthesis of granulation tissue (Dyson and Pond, 1970).

\section{EXPERIMENTAL PROCEDURE}

A Sonacel Multiphon MK II ultrasound machine was used to investigate the heating produced by pulsed ultrasound. This machine is capable of producing ultrasound at three frequencies $(0,75 ; 1,5$ and $3,0 \mathrm{MHz})$ and ( intensities ranging from $0-3,0 \mathrm{~W} / \mathrm{cm}^{2}$. Pulsed beams may be emitted in the ratio of $1: 1$ or $1: 4$.

The experiment was performed using six New Zealand rabbits. Four thermocouples were inserted into the thighs of each rabbit at depths of 5, 10,15 and 20 $\mathrm{mm}$ i.e. into the lateral subcutaneous tissue, muscle, bone marrow cavity and medial subcutaneous tissue respectively. The thermocouples were attached via a multiway switch to a digital voltmeter. Temperature changes produced at the thermocouple junctions were recorded on the voltmeter. The voltmeter readings were converted to temperature values using the calculated factor. The lateral aspect of the thighs were shaved for insonation purposes. The core temperatures of the rabbits were maintained at $38,4^{\circ} \mathrm{C}$ using a homeothermic blanket. The ultrasound was applied by means of a stroking technique over an area of $7 \mathrm{~cm}$ by $5 \mathrm{~cm}$.

In the experiment, pulsed ultrasound at frequencies nf $0,75,1,5$ and 3,0 $\mathrm{MHz}$; intensities of $0,5,1,5$ and 2 , $\mathrm{W} / \mathrm{cm}^{2}$ and pulse ratios of $1: 1$ and $1: 4$ were used. A different rabbit was used for each pulse ratio trial. Recordings were taken for each thermocouple from a digital voltmeter at 3,6,9 and 15 minutes after insonation had started. Insonation was discontinued for a 
Figure 1. Graph representing the thermal and biological effects of ultrasound, using a pulse ratio or 1:4

AMPLITUDE.
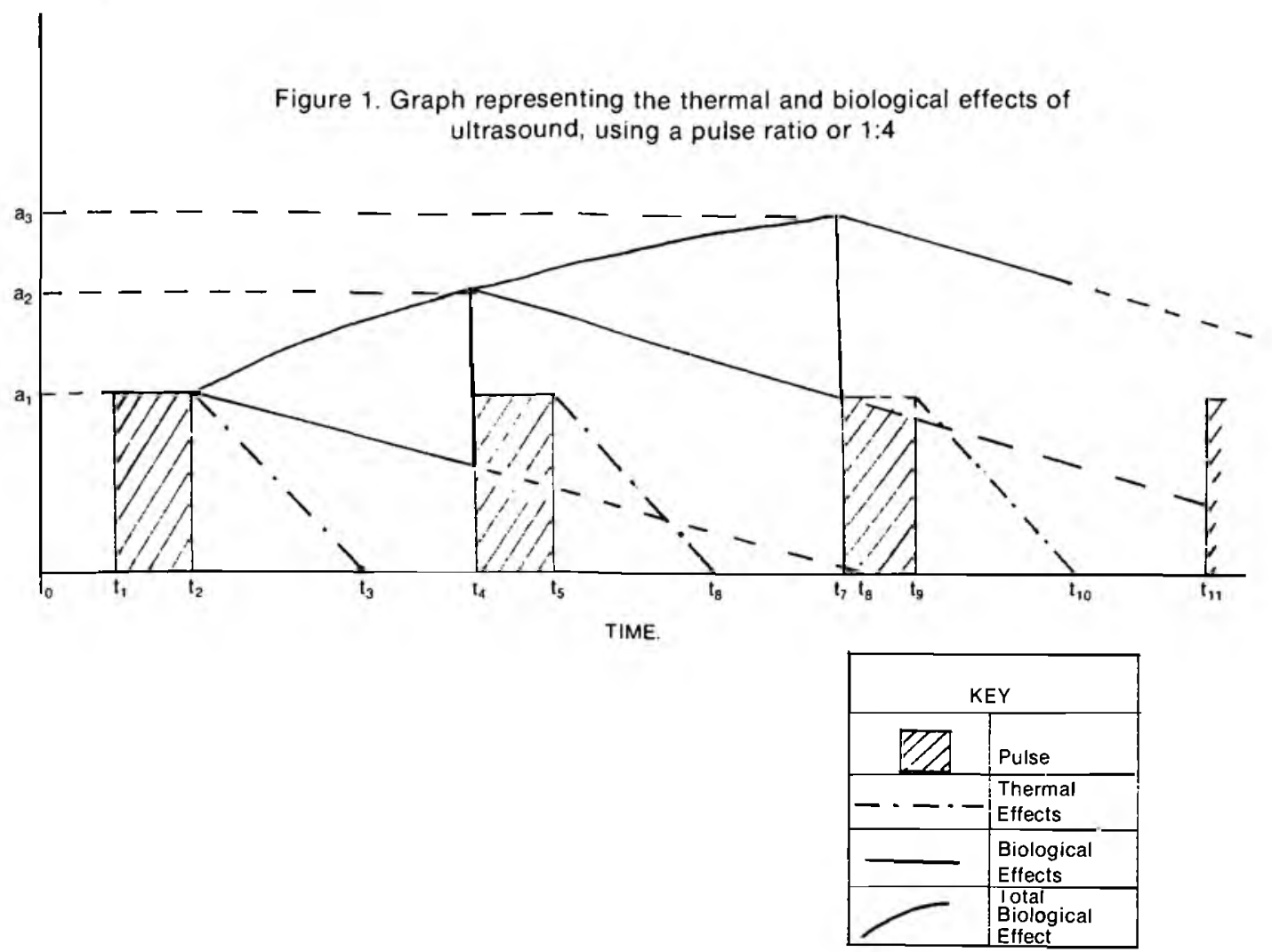

period of 10 minutes between each frequency trial to allow for cooling to take place. A control trial was run to investigate any heating produced by friction due to the moving soundhead.

\section{RESULTS AND DISCUSSION}

(Figure 2)

Cooling occurred in the control experiment due to heat loss by conduction to the cool transducer and gel. Greater heating was obtained with a pulse ratio of $1: 1$ than with a pulse ratio of $1: 4$.

Greatest heating occurred in the lateral subcutaneous tissue. This result can be explained by the fact that fat has a higher coefficient of absorption, a slightly lower specific heat and its thermal conductivity is approximately half of that of the underlying muscle. Another factor is that the intensity of the ultrasonic beam decreases with penetration due to absorption by the tissues. The amount of absorption depends on the coefficient of absorption of each particular tissue, the degree of reflection at each interface, the specific heat and the thermal conductivity of each tissue.

Temperature changes recorded in the muscle were generally lower than those in the lateral subcutaneous tissue. This is due to the decreased energy available for absorption and the lower coefficient of absorption of muscle, however, temperature changes here were greater than those in the medial subcutaneous tissue. This may be due to the fact that muscle is more vascular than fat and vasodilation will produce a greater rise in local temperature. There is also more energy available for absorption in muscle than in the medial subcutaneous tissue.
Fiaure 2 .

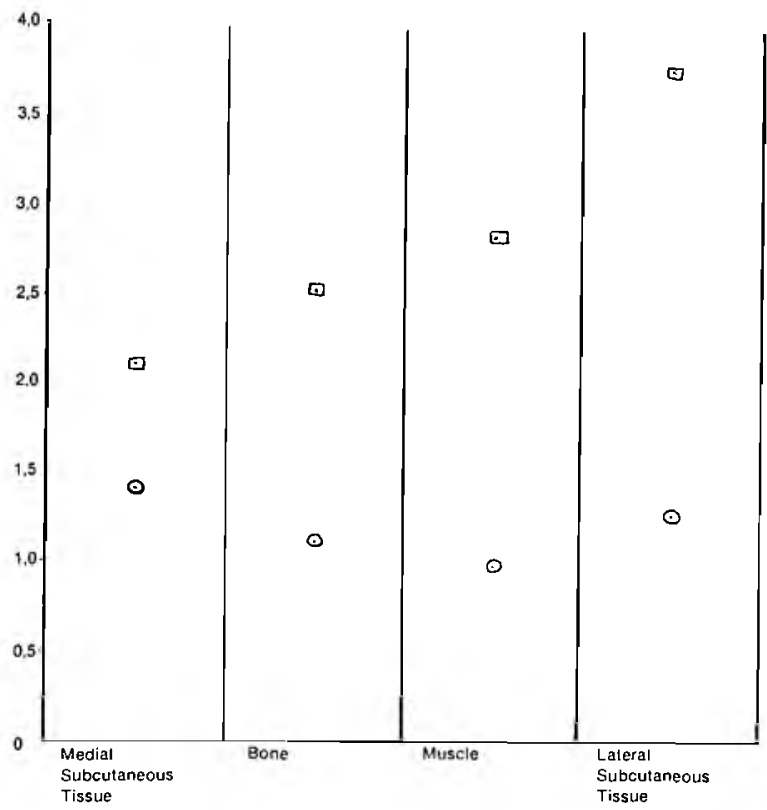




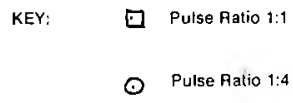

\begin{tabular}{|c|c|c|c|c|}
\hline $\begin{array}{rr} & \emptyset \\
\text { FREQUENCY } \\
(\mathrm{MHz}) & \odot\end{array}$ & 0.75 & 3,0 & 0,75 & 0.75 \\
\hline $\begin{array}{lc} & 0 \\
\text { INTENSITY } \\
\left(W / \mathrm{cm}^{2}\right) & \odot\end{array}$ & 1.5 & 2.5 & 1,5 & 1.5 \\
\hline $\begin{array}{ll} & \mathbf{a} \\
\text { TIME } & \\
\text { (MIN.) } & 0\end{array}$ & 15 & 15 & 15 & 15 \\
\hline
\end{tabular}

GRAPH TO ILLUSTRATE THE COMPARISON OF AVERAGE PEAK TEMPERATURE CHANGES PRODUCED BY CONTINUOUS ULTRASOUND AND PULSED ULTRASOUND AT PULSE RATIOS OF $1: 1$ and $1: 4$.

No marked concentration of heat occurred in bone. An explanation for this is that the thermal conductivity of bone is approximately three times that of muscle. Consequently, any heat accumulation in bone will be dissipated more rapidly than in the soft tissue adjacent to the bone.

Heating in the medial subcutaneous tissue may be attributed to reflection of the ultrasonic beam at the air-skin interface with the resultant increase in energy in this tissue. In addition, heat produced by insonation may stimulate the thermoregulatory mechanism which would result in peripheral cutaneous vasodilation (Summer and Patrick, 1964). This increases the local temperature, influencing the temperature changes recorded in both the medial and the lateral subcutaneous tissues.

The results obtained in this experiment were not consistent with those of Lehmann et al. (1967) who found greatest heating in cancellous bone. The next highest temperatures were recorded in the soft tissues in front of bone. All other temperatures in the soft tissues and bone marrow were lower.

No definite pattern was found showing the effect of frequency on the heat produced. However, it was noted that a frequency of $0,75 \mathrm{MHz}$ produced greatest heating at both pulse ratios. The implication here is that 0,75 $\mathrm{MHz}$ has the greatest ability to interact with the tissues because of the greater wavelength and resultant longer attenuation and half value distance of this frequency. These characteristics cause the beam to be reflected at the interfaces more often, producing greater heating. This explains why it was found that an intensity of $0,5 \mathrm{~W} / \mathrm{cm}^{2}$ only produced heating at a frequency of $0,75 \mathrm{MHz}$.

At a pulse ratio of $1: 1$ the degree of heating is related to the duration of insonation, with greatest heating at 15 minutes. At a pulse ratio of $1: 4$ there was very little variation in temperature after 6 minutes. It was thought that vasodilatation occurred here, resulting in a state of thermal equilibrium i.e. the energy supplied to the tissue being equalled by the energy dissipated via the circulation (Mitchell, 1980).

In the rabbit the relative thickness of subcutaneous fat and musculature is considerably different from that of a human being. Furthermore, the total tissue volume exposed is less. The absorption, reflection and refraction of the ultrasonic beam will therefore be different in human tissues.

\section{CONCLUSIONS}

A pulse ratio of $1: 1$ produces more heating than a pulse ratio of $1: 4$. The greatest temperature changes were recorded in the lateral subcutaneous tissue at both pulse ratios. Heating obtained using a pulse ratio of $1: 1$ was significantly less than that produced by a continuous beam. At a pulse ratio of $1: 1$ the rise in temperature is proportional to the duration of insonation. The effect of frequency on heat production is not clearly defined. Further research in this field is necessary. In this experiment a frequency of $0,75 \mathrm{MHz}$ was shown to have the greatest ability to interact with the tissues. At both pulse ratios an intensity of $0,5 \mathrm{~W} / \mathrm{cm}^{2}$ only produced significant heating at a frequency of $0,75 \mathrm{MHz}$. No heating effects are caused by friction between the transducer and the skin.

Pulsing the beam does not reduce the total biological effect of ultrasound. This should be considered when selecting dosage. Literature reviewing pulsed ultrasound and its effects is limited. Further research in this field is necessary for a more complete understanding of th topic. Further investigation into the effects of pulsed ultrasound on human tissue is essential.

\section{CLINICAL IMPLICATIONS}

- Diameters of areas to be treated should be taken into account when selecting a dosage for insonation i.e. the effects of beams reflected off the bonetissue interface should be considered, as these may result in greater heating and mechanical effects.

- If complete elimination of heating effects is required a pulse ratio of $1: 4$ or less should be used.

- According to authorities the minimum temperature rise necessary to be of therapeutic significance is not known. Therefore the heating effects of pulsed ultrasound, although less than continuous ultrasound, cannot be ignored.

- Even though the total energy output is not maintained when the ultrasound beam is pulsed, the intensity of each wave is unaltered. Pain, due to damage caused by high intensities may only be felt after damage has occurred, unlike periosteal pain caused by overheating, which acts as a warning signal when using a continuous beam.

\section{References}

Bauer, A. W. (1954). The present position of ultrzsonics. Brit. J. Phys. Med. 17, $97-101$.

Dyson, M. and Pond. J. B. (1970). The effect of pulsed ultrasound on tissue regeneration. Physiother., 56, $136-142$.

Faris, P. (1969). Ultrasound: The dosage question. Physiother. Canada. 21, 155 - 159.

Griffin, J. E. (1966). Physiological effects of ultrasonic energy as it is used clinically. Phys. Ther. $4618-26$.

Griffin, J. E., Elmternacht, J. L., Bowmaker, K. L. (1970). Results of frequency differences in ultrasonic therapy. Phys. Ther. 50, $481-485$.

Lehman, J. F., Delateur, M. D., Warren, C. G. and Stonebridge, B. S. (1967). Heating produced by ultrasound in bone and soft tisuue. Arch. Phys. Med. and Rehab. 48, 397 - 401 .

Licht, S. (1972). Therapeutic Heat. 2nd ed. Waverly Press. Baltimore, Maryland.

Miller, F. E. and Weaver, J. B. (1954). Ultrasound therapy. Physical Therapy Review. 34, 562 - 566.

Mitchell, D. (1980). Physiology Department, University of the Witwatersrand. Personal communication.

Scott, P. M. (1975). Clayton's Electrotherapy and Actinotherapy. Baillière Tindall. London.

Summer, W. and Patrick, M. K. (1964). Ultrasonic Therapy. Elsevier. Amsterdam. 